\title{
RAD51 Gene Mutation Negative
}

National Cancer Institute

\section{Source}

National Cancer Institute. RAD51 Gene Mutation Negative. NCI Thesaurus. Code C159782.

A genetic finding indicating that RAD51 gene mutations have not been detected in a sample. 